\title{
Władysława Szulakiewicz, Wladysław Seredyński. Studium z dziejów pedagogiki galicyjskiej, Rzeszów 1995, sa 166
}

7 tom serii zatytułowanej „Galicja i jej dziedzictwo" zostal poświęcony twórczości Whadyshawa Seredyniskiego. Autorka tej ciekawej książki jest Wladysława Szulakiewicz - adiunkt w Wyższej Szkole Pedagogicznej w Rzeszowie. Monografia została bardzo starannie wydana przez wydawnictwo uczelniane w Rzeszowie w 1995 roku.

Praca składa się z 2 części - pierwsza: $W$. Sered yński i jego czasy, druga: Dorobek twórczy Seredyńskiego i jego znaczenie dla teorii i praktyki pedagogicznej. Konstrukcja pracy w swoim zamyśle jest bardzo klarowna, choć podział części pierwszej na kilkustronicowe rozdziały jest nieco sztuczny.

W części drugiej mamy rozdziały, które kolejno tworzą 1. kontekst twórczości Seredyńskiego - Glówne prady w pedagogice XIX wieku $i$ ich popularyzacja na terenie Galicji, 2. właściwą analize twórczości tego pedagoga - Dorobek pedagogiczny Sered yrískiego, 3. uwarunkowania i związki myśli Seredyńskiego $z$ literaturą pedagogiczna obca i wlasna. Ostatni rozdział wykracza nieco poza ramy problemu badawczego, bowiem dotyczy Dorobku historyczno-literackiego Seredyńskiego, ale co najmniej z dwu powodów taka decyzja była sluszna. Po pierwsze swoistym kanonem badań w okresie przełomu XIX/XX wieku było odwoływanie się do pierwiastków historycznych i literackich - jako składowych wiedzy pedagogicznej, po wtóre - współczesna metodologia historii wychowania oczekuje analiz historycznych. Rozprawę zamykają bibliografie: źródłowa - prace Seredyńskiego w ukladzie chronologicznym oraz wybranych opracowań. Trzeba przyznać, że książka powstała w oparciu o wyjątkowo bogaty zbiór źródel archiwalnych pochodzacych z Archiwum Państwowego w Rzeszowie, AGAD, APAN, AUJ oraz ze zbiorów prywatnych.

Część biograficzną książki otwiera rozdział analizujący sytuację społeczną i kulturalną Ga- licji w okresie autonomii. $\mathbf{Z}$ metodologicznego punktu widzenia przyjęcie takiej perspektywy badawczej sugeruje, że analizowana postać reprezentuje bardziej pedagogikę praktyczn̨̨ niż teoretyczną, co znajduje swoje potwierdzenie w zakończeniu pracy. Stąd znajdziemy w tej książce znacznie więcej szczególowych dyrektyw kształcenia i wychowania młodzieży, mniej zaś wnioskowania $\mathrm{i}$ interpretacji wielkich systemów filozoficzno-pedagogicznych. Po części jest to uzasadnione, bowiem twórczość Seredyńskiego przypada na okres dominacji minimalistycznej filozofii pozytywistycznej, która nota bene odżegnywała się od wszelkich filozoficznych (metafizycznych) wizji człowieka i jego wychowania. Dlatego też stosując Arystoteleska klasylikacje wiedzy można powiedzieć, że prace Seredyńskiego mieściły się na pograniczu techne i wiedzy naukowej!

Prezentując środowisko rodzinne autorka skupiła się - co jest dość częste w biografistyce - na osobie ojca, tym bardziej, że jego wpływ na syna, squdząc po wspólnych zainteresowaniach badawczych, mógł być znaczący. Tymczasem niczego nie dowiadujemy sie o matce - być może brak było wystarczających źródel, na podstawie których można w miare obiektywnie nakreślić jej sylwetke.

Bardzo syntetycznie i jednocześnie gruntownie źródlowo przedstawila autorka okres edukacji szkolnej i uniwersyteckiej Seredyńskiego. Krótkie i treściwe portrety jego nauczycieli tworza obraz atmosfery naukowej i wychowawczej, w której kształtowała się jego osobowość. Ciekawie, z punktu widzenia jego rozwoju naukowego, ksztaltowała się lista autorów, z których dzieł korzystał przygotowując się do egzaminu doktorskiego. Obok autorów niemieckojęzycznych (Pestalozzi, Benecke) mamy luminarzy polskiego romantyzmu (Cieszkowski, Libelt, Trentowski) choc w tym gronie zabrakło J. HoeneWrońskiego.

\footnotetext{
' Zgodnie z wypracowanymi na II Zjeździe PTP definicjami - twórczóx́ Seredyńskiego kwalifikuje gię do kategorï myili podagogicznej $z$ racji dość lużnego powiq̨zania stawianych przzzeń tez oraz przewagi prakıyki jako źródła i celu refleksji.
} 
W tym miejscu warto podkreślić, że autorka zręcznie wykazała w swojej interpretacji myśli pedagogicznej Seredyńskiego fakt, iż choć on sam nie zbudowal zwartego systemu pedagogicznego, musial twórczo przewartościować dorobek koryfeuszy tamtej epoki i wykorzystać go w nowej, pozytywistycznej szacie. W tym miejscu czytelnik oczekiwal nieco bardziej poglębionej analizy owych wewnętrznych przeobrażeń. Rozdział III kończy prezentacja nieopublikowanej rozprawy doktorskiej Seredyńskiego zatytułowanej Rys dziejów piśmiennictwa mézów stanu i statystów w Polsce, która zawiera poza mniej interesującymi historyka wychowania zagadnieniami związanymi z dziejami polityki Jagiellonów także rozważania nad traktatem królowej Elżbiety (s. 36). Jeśli weźmiemy pod uwagę fakt, że Seredyński doktoryzował się w 1895 roku to swą analiza wyprzedził o 37 lat prace Antoniego Danysza, którego uważa się za jednego z prekursorów badań w zakresie zabytków nowożytnej myśli pedagogicznej. Porównanie obu prac mogłoby pokazać pewne aspekty rozwoju historiografii pedagogicznej. Ten wątek nie był kontynuowany przez autorkę.

Bio-doksografia Seredyńskiego może być uznana za wzorcowa; obok pracy naukowej (autorka daje tu bogatą prezentację jego związków z Akademią Umiejętności i Towarzystwem Naukowym Krakowskim) przedstawiono także jego ożywioną działalność pedagogicznタ, m.in. w słynnym gimnazjum św. Anny w Krakowie.

Analiza twórczości naukowej rozpoczyna się dopiero w II części, z której rozdział VI (Glówne prądy w pedagogice $X I X w . i$ ich popularyzacja na terenie Galicji) jest wprowadzeniem w klimat intelektualny tamtych czasów. Na rozdział ten składa się analiza pedagogiki Pestalozziego, Herbarta i Spencera. Jak można przypuszczać, stanowi on wraz $\mathrm{z}$ rozdziałem VIII (Europejska i polska myśl pedagogiczna w dorobku pedagogicznym Seredyńskiego) swoistą klamrę wyjaśniająca praktykę i teorię, którą uprawiał Seredyński. Wydaje się, że dla większej harmonii obok autorów zachodnich należałoby w kilku syntetycznych podrozdzia- łach (zachowując koncepcję struktury pracy przyjęta przez autorkę) wyeksponować polską myśl pedagogiczną: J. Hoene-Wrońskiego, B. Trentowskiego, A. hr. Cieszkowskiego.

Wysiłek badawczy autorki został skierowany, na tym etapie badań, na wyeksponowanie tych wątków pedagogiki Pestalozziego, Herbarta i Spencera, które w podobnej formie zostały przyjęte przez środowisko galicyjskich pedagogów. Nauswa się w tym miejscu pytanie, czy metoda historyczna ograniczająca się do rozstrzygnięcia, które z założeń czy pojedynczych myśli zostały przejęte, czy ta metoda w badaniach myśli pedagogicznej jest wystarczająca. Wydaje się, że korzystniejsze mogło być dla pełniejszego zrozumienia myśli Seredyńskiego pokazanie np., że podstawowy (i nierozwiązany) problem Pestalozziego: sztuka czy metoda wychowania - Herbart rozstrzyga na korzyść metody, a Rein i Ziller doprowadzają do skrajności². Mając określony pewien kierunek rozwoju danej idei można wyraźniej zidentyfikować miejsce badanego pedagoga. W. Szulakiewicz nie koncentrowała się wyłącznie na recepcji samego Pestalozziego, wskazała na kontynuatorów jego idei wychowawczych w osobach Diesterwega i Frōbla. Merytoryczne powiązania zostały jednak słabiej wyeksponowane niż zwiazzki formalne. Wydaje się, że autorka kierowała się w tym fragmencie swej pracy metodą charakterystyczną dla L. Chmaja (nazwijmy ja personalną), gdy tymczasem korzystniejsz̨ byłaby metoda B. Nawroczyńskiego (syntetyczno-problemowa).

Mniej miejsca, ale odwrotnie do wagi problemu, poświęciła autorka herbartyzmowi, który oficjalnie $i$ nieoficjalnie dominowal $w$ pedagogice Galicji. Wyeksponowanie niuansów kontynuacji i krytyki tej doktryny przez pedagogów galicyjskich byłoby ważnym wprowadzeniem w twórczość Seredyńskiego. W tym miejscu warto również zauważyć, że pedagogika Herbarta i Spencera pod wieloma wzgledami stały wobec siebie w opozycji (np. idealizm, racjonalizm - biologizm, utylitaryzm; czy neohumanizm - realizm w zakresie kształcenia). Ponieważ twórczość Spencera - jak można

\footnotetext{
${ }^{2}$ Warto tu dodać, ze nie tylko $w$ II polowie XIX wieku interesowano się żywo pedagogika Pestalozziego, ale również w okresie międzywojennym. Niewielu jednak autorów uświadamiako sabie zwiqzki tej pedagogiki z filozofiq krylycznq Kanta, $z$ Klórej wyrosly bardzo noíne teorie pedagogiczne.
} 
wnioskować na podstawie książki - była nieobecna w myśli pedagogicznej Seredyńskiego (patrz rozdział VIII Europejska $i$ polska mysl pedagogiczna w dorobku pedagogicznym Seredyńskiego) można było z niej zrezygnować, a więcej uwagi poświęcić Herbartowi i późniejszym mutacjom jego pedagogiki.

Być może obecność pierwiastków herbartyzmu we współczesnej praktyce pedagogicznej zawdzięczamy w jakimś stopniu pedagogom galicyjskim. Jest to ciekawy $i$ ważny problem, także dla wspłóczesnej refleksji pedagogicznej, który W. Szulakiewicz z racji swego warsztatowego przygotowania mogłaby w przyszłości poddać naukowej analizie. We wspólczesnej literaturze historyczno-pedagogicznej nadal brak tak podstawowej pracy, jaka jest polska recepcja herbartyzmu.

Innym problemem, który wymagałby gruntownego i syntetycznego przemyślenia jest pytanie o to, czy możemy mówić o „galicyjskiej myśli pedagogicznej", czy mamy raczej do czynienia ze zbieżnością warstwy normatywnej przy jednoczesnej mozaice przesłanek. Wnioski w tym zakresie byłyby ważnym wkładem w teorię badań polskiej myśli pedagogicznej.

W dorobku pedagogicznym Seredyńskiego wyeksponowała W. Szulakiewicz m.in. projekty organizacyjne, metodyczne, twórczość w zakresie podręczników. Taka selekcja zagadnień sama w sobie jest już pewną wskazówką oceny badanej twórczości - sugeruje ona praktyczny charakter zainteresowan naukowych Seredyńskiego. I choć autorka podkreśla, że usiłował on zbudować własną pedagogike, to jednak wydaje się trudnym określenie podstawowych jej tez i zasad, które by ją fundowały. Niewątpliwie był Seredyński animatorem i reformatorem życia oświatowego w Galicji. Jak podkreślała autorka [Seredyński] „biorąc pod uwage najnowsze tendencje w pedagogice $i$ w oświacie dostosowywal plany nauczania do potrzeb kształcącej się młodzieży i warunków społeczno-politycznych Galicji"(s. 87). Była to więc pedagogika typu techne a nie sofia.
Poważną część twórczości Seredyńskiego stanowia tłumaczenie dzieł Gustawa A. Lindnera. Wybór Seredyńskiego nie był przypadkowy - literatura niemieckojęzyczna oblitowała w prace z zakresu pedagogiki i jej subdyscyplin. Seredyński pisząc Zasady logiki $i$ dydaktyki ogólnej dla użytku seminariów nauczycielskich oraz Ogólne zasady nauki wychowania dla użytku seminariów nauczycielskich polskich wyraźnie preferował tego pedagoga. Nasuwa się pytanie o źródła takiej decyzji - czy był to wybór subiektywny czy obiektywny, w oparciu o kryteria merytoryczne czy pozamerytoryczne, czy przesłanką były zbieżne założenia teoretyczne czy praktyczne. Uzasadnienie tego wyboru być może wyjaśniłoby, jakimi drogami rozwijała się rodzima myśl pedagogiczna pod zaborami ${ }^{3}$.

W książce W. Szulakiewicz dadzą się dostrzec kolejno po sobie występujące wątki badań. Po części analitycznej, do której zaliczyłbym rozdziały I - VII następuje część syntetyczna (rozdziały VIII - LX). We wstępie rozdziału VIII autorka sformułowała ogólną myśl: „podlądy pedagogiczne Seredyńskiego pomimo oddziaływania nań różnych prądów pedagogiki zachodniej nie sa zlepkiem różych myśli. W swoich rozważaniach pedagogicznych umiejętnie posługiwał się dotychczasowymi osiągnięciami wybitnych pedagogów Europy Zachodniej i przystosował je do potrzeb własnego narodu" (s. 130). Powstaje więc w tym miejscu pytanie natury metodologicznej: czy idea narodowa, która przewija sį̨ na kartkach książki W. Szulakiewicz jest wystarczającym kryterium oryginalności (czyt samodzielności) twórczości Seredyńskiego?

Autorka bardzo umiejętnie zaprezentowała współbrzmienie poglądów omawianego pedagoga $\mathrm{z}$ niektórymi ideami nawet bardziej odległej tradycji (Komeński, Locke, Rousseau). Ciekawa w kontekście przytoczonych myślicieli byłaby pogłębiona interpretacja pojęcia natury człowieka, które w dziejach myśli pedagogicznej ma swoją długa historię $\mathrm{i}$ wielorakie interpretacje. Jest to przecież jedno z kluczowych

Notka biograficzna Lindnera zostata umieszczona w końcowej czéśi ksjążli, choć nazwisko pojawia aį̣ wielokrolnie we wczé́niejszych partiach. Ona również nie wyjaśnja (choć sugeruje możliwą interpretację) przyczyn, dla których Seredyńskj opjeral się na Lindnerze, a nie wprost na samym Herbarcie. Podobnic rzecz się ma z Rysem dziejów..., który wedhug autorki powsta w oparciu o badania wlasne i prace K. Schmidta, L. Kellnera, J. Lukaszewicza, B. Trenlowskiego. W tym miejscu czytelnik odsylany jest do rozdza hu 10, którego w ksiqzice nie ma Wydaje się, że taki rozdzial poświęcony twórczosici bisloryczno-pedagogicznej bytby bardzo cenny dla rozwoju badań wspólczesnej historiografii historii wychowania. 
pojęć, bowiem stanowi ono wyraz usiłowań wielu pokoleń i wielu kultur zmierzających do określenia, kim jest czlowiek. Przytoczone przez autorke poglądy Seredyńskiego wskazuja raczej na mało oryginalne rozstrzygnięcie przez niego tego problemu i silna tendencje proherbartowska.

Wydaje się, że na koniec można pokusić się o syntetyczny wniosek: dorobku pedagogicznego Seredyńskiego nie należy postrzegać jako prostej kompilacji obiegowych zasad pedagogicznych i najbardziej popularnych teorii, ale jednocześnie nie można powiedzieć, że reprezentował wyraźny, określony kierunek w myśli pedagogicznej. Nie wypracował również własnej doktryny pedagogicznej koncentrując się (w duchu minimalistycznego pozytywizmu) na bieżących, konkretnych rozwiązaniach programowych i edytorsko-organizacyjnych. Efekty jego pracy pozwalają zaliczyć go do wybitnych postaci polskiej oświaty pod zaborami.

Autorce tej cennej książki, w oczekiwaniu na kolejne, równie ważkie, należy pogratulować ciekawej merytorycznie i bogatej erudycyjnie pracy.

Slawomir Sztobryn

\section{Noty}

\section{Galicja i jej dziedzictwo. Tom III pt. Nauka i oświata, red. A. Meissner i J. Wyrozumski, Rzeszów 1995, Wydawnictwo Wyższej Szkoly Pedagogicznej, ss. 286.}

W ramach seryjnego wydawnictwa pt. "Galicja i jej dziedzictwo" ukazal się w 1995 trzeci tom poświęcony problemom edukacji i nauki. Zawiera on materiały zaprezentowane na ten temat podczas międzynarodowej konferencji naukowej zorganizowanej w 1992 roku w Lancucie i Rzeszowie (przede wszystkim podczas obrad osobnej sekcji, w której omawiano te problematykę).

Publikacja składa się z dwóch części, z których pierwsza dotyczy zagadnień nauki, druga - problemów oświaty. W części pierwszej zamieszczono teksty, których przedmiotem rozważań są kolejno: studia młodzieży polskiej (wywodzącej się przede wszystkim $z$ terenów południowej i wschodniej Polski) na uniwersytetach Europy Zachodniej - od czasów średniowiecza do połowy osiemnastego wieku (Ryszarda Kazimierza Lewańskiego), życie naukowe w autonomicznej Galicji (Juliana Dybca), narodziny, rozwój i znaczenie galicyjskich to- warzystw naukowych w zakresie humanistyki (Jerzego Starnawskiego), działalność Towarzystwa Naukowego im. T. Szewczenki i jego rola w narodowym odrodzeniu Ukraińców (Mykoły Muszynki), wkład Galicji w rozwój nauk pedagogicznych (Andrzeja Meissnera), wybrane zagadnienia myśli pedagogicznej Galicji i Królestwa Polskiego w drugiej połowie XIX wieku - w ujęciu komparatystycznym (Władysławy Szulakiewicz), galicyjskie początki neoscholastycznej odnowy polskiego katolicyzmu (Czesława Głombika), rola rzeszowian w rozwoju nauk medycznych w wieku XIX i XX (Lesława Grzegorczyka).

Część druga zawiera opracowania, które poświęcone sa: polityce szkolnej w Galicji w latach 1866-1890 (Renaty Dutkowej), rozwojowi szkolnictwa ukraińskiego w Galicji (L. H. Bajka), roli gimnazjum galicyjskiego $w$ procesie kształtowania się inteligencji polskiej (Leszka Śliwy), szkołom średnim pogranicza galicyjsko- 